\title{
Znaczenie form ekonomii społecznej dla przeciwdziałania zjawisku bezdomności
}

\author{
Magdalena Małecka-Łyszczek* \\ Streszczenie: Opracowanie analizuje wybrane formy ekonomii społecznej poprzez pryzmat ich „użyteczności” \\ w inkluzji osób bezdomnych, w ich upodmiotawianiu, upełnomocnianiu. Chodzi zatem o wyeks- \\ ponowanie tego, co pozwala na przezwyciężanie narastającego wykluczenia społecznego, umoż- \\ liwiając pełniejsze uczestniczenie osób bezdomnych w życiu społecznym, w formułujących się \\ w ramach społeczeństwa wspólnotach. \\ Słowa kluczowe: ekonomia społeczna, bezdomność, inkluzja, wykluczenie społeczne.
}

\section{Bezdomność jako przyczyna i skutek wykluczenia społecznego}

Zakres zainteresowań prawa administracyjnego pełen jest obszarów dotykających tzw. trudnych kwestii społecznych (wicked problems). Bezdomność, tak ściśle, nierozerwalnie połączona z jednostką ludzką, jest problemem nie tyle skomplikowanym, co bardzo skomplikowanym. Jest jednocześnie jedną z najskrajniejszych i najbrutalniejszych form wykluczenia społecznego [Krajowy Program, 2014]. Podejmowane działania z różnym natężeniem wpływają na rozwiązanie rozmaitych dylematów połączonych z bezdomnością [zob. m.in.: Karta, bdw; MRPiPS, 2018], jednakże cały czas zostawiając poczucie koniecznego wysiłku, który nadal musi być podejmowany $w$ tym tak trudnym $\mathrm{i}$ dotkliwym obszarze.

Bezdomność jest problemem, który może być badany, po pierwsze, z perspektywy samej osoby bezdomnej (jako niezamieszkującej w lokalu mieszkalnym w rozumieniu przepisów o ochronie praw lokatorów i mieszkaniowym zasobie gminy i niezameldowaną na pobyt stały, w rozumieniu przepisów o ewidencji ludności, a także osobę niezamieszkującą w lokalu mieszkalnym i zameldowaną na pobyt stały w lokalu, w którym nie ma możliwości zamieszkania (zgodnie z art. 6 pkt.8 ustawy z dnia 12 marca 2004 r. o pomocy społecznej'). Ponadto, również z perspektywy wspólnoty, w ramach której osoba ta funkcjonuje. Stąd wspólnoty samorządowe wykonują szereg zadań, m.in. właśnie z obszaru pomocy społecznej, te zaś odnieść możemy wprost do kwestii bezdomności (przykładowo: art. 7 pkt 3 u.p.s., art. 17 ust. 1 pkt 3, 7 i 15 u.p.s., art. 48a u.p.s., art. 39 ust. 3 u.p.s.).

Samo wykluczanie to usunięcie, eliminowanie, rugowanie $z$ udziału (uczestnictwa) w określonym obszarze życia społecznego. Dotyka sytuacji, gdy ktoś formalnie przynależy do danej grupy społecznej, wspólnoty

T.j. Dz.U. z 2018 r. poz. 650, 700 z późn. zm., dalej: u.p.s.

\footnotetext{
* Magdalena Małecka-Łyszczek

Katedra Prawa Publicznego

Uniwersytet Ekonomiczny w Krakowie

ul. Rakowicka 27, 31-510 Kraków

e-mail:maleckam@uek.krakow.pl
} 
- ale nie ma możliwości skorzystania z dobrodziejstw tej przynależności [Aleksander, 2012, s. 5]. Możemy wskazać na sytuacje, kiedy ktoś miał możliwość korzystania z pewnych dóbr (np. w przypadku osób bezdomnych - mieszkanie), a następnie je utracił. Może jednak również obejmować sytuacje, kiedy jednostka z uwagi na przynależność do określonych grup (rodziny patologiczne, mniejszość narodowa), zostaje już niejako $a b$ initio, pierwotnie pozbawiona szans dostępu do dóbr pożądanych z punktu widzenia prawidłowego funkcjonowania w społeczeństwie (np. lepszej edukacji czy też ściśle w kontekście niniejszego opracowania - lokum) [Kostyło, 2008, s. 12]. W konsekwencji wyróżniam: inkluzję następczą - oznaczającą przywracanie istniejących uprzednio, utraconych przez jednostkę możliwości uczestniczenia we wspólnocie, jak i inkluzję pierwotną jako kreowanie nowych możliwości, które wcześniej po stronie jednostki nie istniały. Nadto, wykluczenie - jako problem szerszy zakresowo od ubóstwa - niekoniecznie dotyczy materialnych aspektów życia, gdyż odnoszone może być również do więzi międzyludzkich [Szarfenberg, Żołędowski, Theiss, 2010, s. 9]. Można także wyróżnić rozmaite aspekty wykluczenia (np. mieszkaniowe, zawodowe, kulturowe, kompetencyjne, cyfrowe) [Małecka-Łyszczek, 2017c, s. 405418]. W przypadku bezdomności mamy do czynienia niejako z wykluczeniem krzyżowym, gdyż łączy się ono, przenika się z tymi innymi możliwymi do wyróżnienia formami. Przykładowo, często problem bezdomności połączony jest z problemem alkoholizmu, bezrobocia, braku dostępu do opieki medycznej [Lipowicz, 2013, s. 130-133]. Dlatego bezdomność to niewątpliwie szczególnie dotkliwy przykład ekskluzji społecznej. Bezdomność może być przy tym zarówno przyczyną wykluczenia społecznego, ale jednocześnie poprzez wskazane powyżej powiązanie $z$ innymi formami ekskluzji, może być jego skutkiem ${ }^{2}$. Ponadto, tak jak w przypadku in genere postrzeganego wykluczenia (i możliwości wyróżnienia osób wykluczonych, jak i potencjalnie zagrożonych wykluczeniem) można mówić zarówno o osobach bezdomnych (realnie bezdomni), jak i o grupie zagrożonych bezdomnością (potencjalnie bezdomni), w odniesieniu do których dotknięcie ich poprzez rozmaite formy wykluczenia skutkować może bezdomnością realną.

\section{Formy ekonomii społecznej jako możliwość przeciwdziałania wykluczeniu społecznemu, w tym bezdomności}

Mając na uwadze powyższe rozważania widoczna jest ciągła potrzeba poszukiwania rozwiązań przeciwdziałających bezdomności [Mędrzycki, 2017, s. 11 i nast.], w tym również w obszarze ekonomii społecznej. Przyjmuję, że uwarunkowana aksjologicznie ekonomia społeczna pozwala na inkluzję społeczną, zapobiega ekskluzji. Niniejsze opracowanie analizuje wybrane formy ekonomii społecznej poprzez pryzmat ich „użyteczności” w inkluzji osób bezdomnych, w ich upodmiotawianiu, upełnomocnianiu. Nie omawia natomiast szczegółowo regulacji prawnych odnoszących się do poszczególnych form, co zostało już w literaturze przedmiotu zaprezentowane ${ }^{3}$.

Chodzi zatem o wyeksponowanie - w kontekście ekonomii społecznej- tego, co pozwala na przezwyciężanie narastającego wykluczenia społecznego, umożliwiając pełniejsze (jak najpełniejsze) uczestniczenie osób bezdomnych w życiu społecznym, w formułujących się w ramach społeczeństwa wspólnot. Warto zauważyć, iż ekonomia społeczna poprzez swoje odniesienie do problemów natury etycz-

Co do przyczyn bezdomności: [Moraczewska, 2013, s. 122124].

Co do zakresu podmiotowego i klasyfikacji pojęcia podmiotu ekonomii społecznej zob.: [Małecka-Łyszczek, 2017a, s. 207-218 i przywołana tam literatura]. 
nej i humanitarnej dostrzeżona została w tak istotnej w kontekście wykluczenia społecznego i przeciwdziałania mu nauce społecznej kościoła katolickiego. Przykładowo w Encyklice Centesimus annus Jan Paweł II podkreślał potrzebę systemu obejmującego trzy podmioty: rynek, państwo oraz społeczeństwo obywatelskie. Natomiast w Encyklice Caritas in veritae zauważono, że sfera ekonomiczna należy do działalności człowieka, i właśnie dlatego, że jest ludzka, powinna być etycznie strukturyzowana i instytucjonalizowana. Potrzeba zatem przestrzeni dla działalności ekonomicznej realizowanej przez podmioty, które „w sposób wolny decydują się kształtować swoją działalność w świetle zasad odmiennych od czystego zysku, nie rezygnując z tego powodu z wytwarzania wartości ekonomicznej". Obok przedsiębiorstw prywatnych i różnego rodzajów przedsiębiorstw publicznych, swoją przestrzeń powinny znaleźć również takie, które stawiają sobie cele społeczne i wzajemną pomoc. Z ich wzajemnej konfrontacji na rynku można oczekiwać pewnego rodzaju skrzyżowania zachowań przedsiębiorczych, a więc wrażliwości na cywilizację ekonomii [Małecka-Łyszczek, 2017b, s. 23].

\subsection{Spółdzielnie socjalne}

Najbardziej charakterystycznym przykładem podmiotu ekonomii społecznej, a jednocześnie przedsiębiorstwa społecznego, jest spółdzielnia socjalna. Spoglądając na wskazany w ustawie z dnia 27 kwietnia 2006 r. o spółdzielniach socjalnych ${ }^{4}$ zakres podmiotów, które utworzyć mogą spółdzielnię socjalną, odnajdujemy pośród nich:

1) osoby bezrobotne, $w$ rozumieniu art. 2 ust. 1 pkt 2 ustawy z dnia 20 kwietnia 2004 r. o promocji zatrudnienia i instytucjach rynku pracy ${ }^{5}$;

2) osoby, o których mowa w art. 2 pkt 1a i 1b ustawy z dnia 13 czerwca 2003 r. o zatrud-

\footnotetext{
4 Dz.U. z 2006 r. nr 94 poz. 651 z późn. zm., dalej: u.s.s. T.j. Dz.U. z 2017 r. poz. 1065 z późn. zm., dalej: u.p.z.i.r.p.
}

nieniu socjalnym ${ }^{6}$, czyli absolwent Centrum Integracji Społecznej ${ }^{7}$ i absolwent Klubu Integracji Społecznej ${ }^{8}$. Dodatkowo przywołać należy art. 16 ust. 1 a u.z.s., zgodnie z którym absolwenci CIS lub absolwenci KIS mogą podjąć wspólną działalność gospodarczą w formie spółdzielni socjalnej na zasadach określonych właśnie w przepisach o spółdzielniach socjalnych;

3) osoby niepełnosprawne, w rozumieniu ustawy z dnia 27 sierpnia 1997 r. o rehabilitacji zawodowej i społecznej oraz zatrudnianiu osób niepełnosprawnych ${ }^{9}$,

4) osoby do 30. roku życia oraz po ukończeniu 50. roku życia, posiadające status osoby poszukującej pracy, bez zatrudnienia w rozumieniu u.p.z.i.r.p.;

5) osoby, o których mowa w art. 49 pkt 7 u.p.z.i.r.p., czyli poszukujący pracy niepozostający w zatrudnieniu lub niewykonujący innej pracy zarobkowej pracy zarobkowej opiekun osoby niepełnosprawnej; z wyłączeniem pobierających świadczenie pielęgnacyjne lub specjalny zasiłek;

6) osoby poszukujące pracy niepozostające w zatrudnieniu lub niewykonujące innej pracy zarobkowej,

7) osoby usamodzielniane, o których mowa w art. 140 ust. 1 i 2 ustawy z dnia 9 czerwca

\footnotetext{
Dz.U. z 2016 r. poz. 1828 z późn. zm., dalej: u.z.s.

Jest to osoba, która przez okres nie krótszy niż 6 miesięcy uczestniczyła w zajęciach w centrum integracji społecznej i otrzymała po zakończeniu uczestnictwa zaświadczenie wydane przez kierownika Centrum. Zaświadczenie potwierdza uczestnictwo w zajęciach i umiejętności nabyte w ramach reintegracji zawodowej i społecznej. Osoba ta jest absolwentem centrum integracji społecznej przez okres 6 miesięcy od dnia zakończenia zajęć w centrum.

Osoba, która uczestniczyła w klubie integracji społecznej przez okres nie krótszy niż 6 miesięcy i posiada ważne zaświadczenie potwierdzające zakończenie uczestnictwa w klubie integracji społecznej, wydawane niezwłocznie przez podmiot prowadzący klub integracji społecznej. Ponadto osoba taka musi zrealizować postanowienia kontraktu socjalnego.

Dz.U. z 1997 r. nr 123 poz. 776 z późn. zm., dalej: u.r.z.s.z.o.n.
} 
2011 r. o wspieraniu rodziny i systemie pieczy zastępczej ${ }^{10}$

- posiadające pełną zdolność do czynności prawnych.

Spółdzielnię socjalną mogą założyć także:

1) inne osoby niż wskazane w ust. 1, o ile liczba tych osób nie stanowi więcej niż 50\% ogólnej liczby założycieli lub też, kolejny przypadek, 70\% ogólnej liczby założycieli, w przypadku gdy spółdzielnię socjalną zakładają osoby o znacznym lub umiarkowanym stopniu niepełnosprawności w rozumieniu przepisów u.r.z.s.z.o.n. albo gdy spółdzielnia prowadzi działalność w zakresie: zadań i usług pomocy społecznej w rozumieniu przepisów u.p.s., rehabilitacji zawodowej i społecznej osób niepełnosprawnych w rozumieniu przepisów u.r.z.s.z.o.n., opieki nad dziećmi do lat trzech, o której mowa w przepisach o opiece nad dziećmi w wieku do lat 3, prowadzenia niepublicznych przedszkoli lub innych form wychowania przedszkolnego, o których mowa w ustawie z dnia 14 grudnia 2016 r. Prawo oświatowe, wspierania rodziny i pieczy zastępczej w rozumieniu u.w.r.s.p.z.

2) organizacje pozarządowe w rozumieniu przepisów o działalności pożytku publicznego i o wolontariacie ${ }^{11}$;

3) jednostki samorządu terytorialnego;

4) kościelne osoby prawne.

Brak zatem wymienienia wprost osób bezdomnych. Wracając jednak do absolwentów CIS i KIS, co regulowane jest u.z.S., jej przepisy stosuje się przecież w szczególności do bezdomnych i to właśnie niniejszy akt prawny jest jednocześnie jednym z nielicznych na gruncie rodzimego porządku prawnego, który odzwierciedla bezpośrednio problematykę bezdomności [Sierpowska, 2016, s. 30]. U.z.s. swym zakresem pod-

\footnotetext{
10 Dz.U. z 2011 nr 149 poz. 887 z późn. zm., dalej: u.w.r.s.p.z.

1 Ustawa z dnia 24 kwietnia 2003 r. o działalności pożytku publicznego i o wolontariacie, t.j.: Dz.U. z 2018 r. poz. 450, 650, 723 z późn. zm., dalej: u.d.p.p.w.
}

miotowym obejmuje m.in. osoby bezdomne realizujące indywidualny program wychodzenia z bezdomności, w rozumieniu przepisów o pomocy społecznej. Zgodnie z art. 49. u.p.s. osoba bezdomna może zostać objęta indywidualnym programem wychodzenia z bezdomności, polegającym na wspieraniu jej w rozwiązywaniu problemów życiowych, w szczególności rodzinnych i mieszkaniowych, oraz pomocy w uzyskaniu zatrudnienia. Program taki jest opracowywany przez pracownika socjalnego ośrodka pomocy społecznej wraz z osobą bezdomną i podlega zatwierdzeniu przez kierownika ośrodka. Jeżeli osoba bezdomna przebywa w schronisku dla bezdomnych, indywidualny program wychodzenia z bezdomności może być opracowany przez pracownika socjalnego zatrudnionego w tej placówce ${ }^{12}$. Jeżeli indywidualny program wychodzenia z bezdomności wykracza poza będące w dyspozycji placówki środki pomocy lub zachodzi konieczność objęcia osoby bezdomnej ubezpieczeniem zdrowotnym, podlega on zatwierdzeniu przez kierownika ośrodka pomocy społecznej. W takim przypadku w programie wskazuje się podmioty odpowiedzialne za realizację poszczególnych postanowień programu. Indywidualny program wychodzenia z bezdomności powinien uwzględniać sytuację osoby bezdomnej oraz zapewniać szczególne wspieranie osobie aktywnie uczestniczącej w wychodzeniu z bezdomności. Program ten, stosownie do potrzeb osoby bezdomnej, może uwzględniać wszelkie środki pomocy, jakimi dysponuje ośrodek pomocy społecznej realizujący program ${ }^{13}$.

Bezdomni są zatem potencjalnymi założycielami spółdzielni socjalnej. Potencjalnymi,

\footnotetext{
2 Realizatorem indywidualnego programu wychodzenia z bezdomności w takim przypadku jest schronisko dla bezdomnych

13 Ponadto za osobę bezdomną objętą indywidualnym programem wychodzenia z bezdomności ośrodek pomocy społecznej opłaca składkę na ubezpieczenie zdrowotne na zasadach określonych w przepisach o świadczeniach opieki zdrowotnej finansowanych ze środków publicznych.
} 
gdyż niewątpliwie wymagali będą bardzo istotnego wsparcia (szczególnie ze strony samorządu, organizacji pozarządowej lub kościelnej osoby prawnej). W praktyce trudno oczekiwać, aby bez tego wsparcia uruchomić i następnie utrzymać na rynku spółdzielnię socjalną. Zarówno podmioty niepubliczne, jak i samorząd, dysponują nieporównywalnie większym potencjałem i doświadczeniem, aniżeli osoby zagrożone wykluczeniem a więc osoby ex definicione wymagające możliwie szerokiego wsparcia. W przypadku, gdy założycielami spółdzielni socjalnej są jednostki samorządu terytorialnego lub organizacje pozarządowe, czy też kościelne osoby prawne - są one zobowiązane do zatrudnienia osób zagrożonych wykluczeniem (minimum pięciu), w terminie sześciu miesięcy od dnia wpisu spółdzielni socjalnej do Krajowego Rejestru Sądowego. Osoby te po 12 miesiącach nieprzerwanego zatrudnienia w takiej spółdzielni mają prawo do uzyskania w niej członkostwa. Jest to rozwiązanie szczególne w stosunku do przewidzianego w Prawie spółdzielczym, gdzie takie uprawnienie nie zostało sformułowane ${ }^{14}$. Jeśli osoba zatrudniona na powyższych zasadach następnie założy lub przystąpi do innej spółdzielni socjalnej, podejmie działalność gospodarczą lub zatrudnienie $u$ innego pracodawcy, rozwiązuje się z nią spółdzielczą umowę o pracę. Jednakże w takim przypadku (w terminie 3 miesięcy od dnia rozwiązania spółdzielczej umowy o pracę) powstaje obowiązek zatrudnienia w jej miejsce nowej osoby, spośród grupy osób zagrożonych wykluczeniem. Istotą działania takiej spółdzielni jest przecież wspieranie osób z grup defaworyzowanych. W powyższej sytuacji spółdzielnia socjalna założona przez jednostki samorządu terytorialnego (jak i organizację pozarządową/ kościelną osobę prawną) może udzielić porę-

\footnotetext{
14 "Spółdzielnia - jako organ samodzielny i samorządny - ma prawo przyjąć ubiegającego się na członka, nie ma natomiast takiego obowiązku". Wyrok z 13.06.1996 r. Sądu Apelacyjnego w Białymstoku I ACr 137/96, LEX nr 31797.
}

czenia pożyczek, kredytów lub zabezpieczenia zwrotu otrzymanej refundacji lub środków na podjęcie działalności gospodarczej, założenie lub przystąpienie do spółdzielni socjalnej. Wkład organizacji pozarządowych, kościelnych osób prawnych lub jednostek samorządu terytorialnego może polegać też na przeniesieniu lub obciążeniu własności rzeczy lub innych praw, a także na dokonaniu innych świadczeń na rzecz spółdzielni socjalnej, w szczególności na wykonywaniu świadczeń przez wolontariuszy lub pracowników jednostek samorządu terytorialnego, kościelnych osób prawnych lub organizacji pozarządowych (art. 5a u.s.s.). Dodatkowo należy tutaj przywołać rozporządzenie Ministra Rodziny, Pracy i Polityki Społecznej z dnia 14 lipca 2017 roku w sprawie przyznawania środków na podjęcie działalności na zasadach określonych dla spółdzielni socjalnych ${ }^{15}$.

Dlatego instytucja spółdzielczości socjalnej jest jednym z przejawów ograniczania ekskluzji społecznej, realizując program aktywizacji zawodowej osób zaliczanych do grupy tzw. niskiej zatrudnialności (niewątpliwie również i osób bezdomnych), pozwalając na integrację słabszych grup z resztą społeczeństwa [zob: Blicharz, 2017, s. 223]. Przyjąć należy, iż model spółdzielni socjalnej reintegrującej osoby bezdomne realizujące indywidualny program wychodzenia z bezdomności służy podniesieniu efektywności systemu aktywizacji społecznej i zawodowej tej grupy [Gołębiowska, 2015, s. 11]. Praktycznym przykładem niniejszych założeń może być chociażby Wrocławska Spółdzielnia Socjalna powstała w 2015 r., której założycielami są Towarzystwo Pomocy im. św. Brata Alberta i Fundacja św. Józefa ${ }^{16}$, czy też Wielobranżowa Spółdzielnia Socjalna Arte w Bielawie ${ }^{17}$. Można wskazać także na działania podejmowane w województwie świętokrzyskim, gdzie w ramach

\footnotetext{
15 Dz.U. z 2017 r. poz. 1379.

16 http://wroclife.pl/nasze-miasto/bezdomny-nie-oznaczabezrobotny-wroclawska-spoldzielnia-socjalna/.

7 http://arte.bielawa.pl/.
} 
Szwajcarsko-Polskiego Programu Współpracy prowadzony jest projekt "Ekonomia społeczna - rozwój z przyszłością", którego celem jest m.in. zdobycie wiedzy przez jego uczestników w zakresie możliwości zakładania spółdzielni socjalnych we współpracy z samorządami gminnymi w celu wspierania procesu wychodzenia $z$ bezdomności. Przedsięwzięcie jest adresowane do przedstawicieli organizacji pozarządowych z województwa świętokrzyskiego prowadzących schroniska dla bezdomnych kobiet i mężczyzn ${ }^{18}$. Oczekiwać należy jednocześnie dalszych zmian w warstwie ustawowej, które wpierały będą osoby bezdomne w tym obszarze [MRPiPS, 2017].

\subsection{Centra Integracji Społecznej i Kluby Integracji Społecznej}

Również Centra Integracji Społecznej czy też Kluby Integracji Społecznej stanowią potencjalną możliwość dla działań inkluzyjnych w odniesieniu do osób bezdomnych czy też potencjalnie zagrożonych bezdomnością. Podmioty reintegracyjne tworzone są w celu reintegracji zawodowej i społecznej osób, dla których są adresowane podejmowane przez nie działania. Podstawy dla funkcjonowania wymienionych podmiotów reintegracyjnych stworzyła uchwalona w 2003 r. u.z.s. Ustawa ta swoje regulacje kieruje do osób, które podlegają wykluczeniu społecznemu i ze względu na swoją sytuację życiową nie są w stanie własnym staraniem zaspokoić swoich podstawowych potrzeb życiowych. Są to jednostki, które znajdują się w sytuacji powodującej ubóstwo oraz uniemożliwiającej lub ograniczającej uczestnictwo w życiu zawodowym, społecznym i rodzinnym. W tak zarysowanym zakresie mieszczą się w szczególności bezdomni realizując indywidualny program wychodzenia $\mathrm{z}$ bezdomności. Zadania określone $w$ ustawie realizowane są poprzez zatrudnienie socjalne, co oznacza zapewnianie wskazanym

18 http://ekonomiaspoleczna.kielce.uw.gov.pl/spp. powyżej osobom możliwości uczestnictwa w zajęciach prowadzonych przez CIS-y, KIS-y, jak i możliwość zatrudnienia wspieranego, przez które rozumie się udzielanie wsparcia o charakterze doradczym i finansowym osobom objętym zakresem podmiotowym ustawy w utrzymaniu aktywności zawodowej umożliwiającej podjęcie zatrudnienia, prac społecznie użytecznych w rozumieniu przepisów o promocji zatrudnienia i instytucjach rynku pracy, założenie lub przystąpienie do spółdzielni socjalnej lub podjęcie działalności gospodarczej. Zarówno CIS-y, jak i KIS-y mają na celu reintegrację społeczną (oznaczającą działania, w tym również o charakterze samopomocowym, mające na celu odbudowanie i podtrzymanie $u$ osoby uczestniczącej w zajęciach umiejętności uczestniczenia w życiu społeczności lokalnej i pełnienia ról społecznych w miejscu pracy, zamieszkania lub pobytu), jak i reintegrację zawodową (oznaczającą działania mające na celu odbudowanie i podtrzymanie u osoby uczestniczącej w zajęciach zdolności do samodzielnego świadczenia pracy na rynku pracy). Integracja społeczna jest wprost osadzona w kontekście współuczestniczenia w funkcjonowaniu wspólnoty lokalnej, konkretnego związku przymusowego, do którego przynależy uczestnik centrum/klubu, co łączyć można z lokalnym zakorzenieniem ekonomii społecznej. W przypadku CIS-ów reintegracja społeczna zawodowa i społeczna realizowana jest poprzez:

1) kształcenie umiejętności pozwalających na pełnienie ról społecznych i osiąganie pozycji społecznych dostępnych osobom niepodlegającym wykluczeniu społecznemu,

2) nabywanie umiejętności zawodowych oraz przyuczenie do zawodu, przekwalifikowanie lub podwyższanie kwalifikacji zawodowych,

3) naukę planowania życia i zaspokajania potrzeb własnym staraniem, zwłaszcza przez możliwość osiągnięcia własnych 
dochodów przez zatrudnienie lub działalność gospodarczą,

4) uczenie umiejętności racjonalnego gospodarowania posiadanymi środkami pieniężnymi (art. 3 ust.1 u.z.s.).

Centrum, w ramach prowadzonej reintegracji zawodowej, może prowadzić działalność wytwórczą, handlową lub usługową oraz działalność wytwórczą w rolnictwie, jednakże $z$ wyłączeniem działalności polegającej na wytwarzaniu i handlu wyrobami przemysłu paliwowego, tytoniowego, spirytusowego, winiarskiego, piwowarskiego, a także pozostałych wyrobów alkoholowych o zawartości alkoholu powyżej 0,5\% oraz wyrobów z metali szlachetnych albo z udziałem tych metali. Działalność ta nie jest działalnością gospodarczą w rozumieniu ustawy z dnia 6 marca 2018 r. Prawo Przedsiębiorców ${ }^{19} \mathrm{i}$ może być prowadzona jako statutowa działalność odpłatna pożytku publicznego w rozumieniu u.d.p.p.w. (art. 9 u.z.s.).

Okres próbny dla potencjalnego uczestnika centrum wynosi jeden miesiąc, a po jego pomyślnym zakończeniu, kierownik ośrodka pomocy społecznej, na wniosek kierownika centrum, kwalifikuje uczestnika do uczestnictwa w zajęciach w centrum. Okres uczestnictwa w zajęciach może trwać do jedenastu miesięcy, jednakże jeśli analiza stanu realizacji programu uzasadnia potrzebę przedłużenia okresu uczestnictwa (także w przypadku tworzenia spółdzielni socjalnej lub podjęcia działalności gospodarczej przez uczestnika zajęć w Centrum), istnieje taka możliwość (art. 15 ust. 1-3 u.z.s.). Chodzi bowiem o dopasowanie podejmowanych działań do faktycznej sytuacji i potrzeb konkretnej osoby, co może wymagać dodatkowego rozłożenia działań w czasie.

Analogiczne rozwiązania przyjęto w odniesieniu do KIS-ów, z tą różnicą, iż w odniesieniu do samorządu jako instytucji tworzącej, ustawodawca ograniczył się tylko do podstawowej

19 Dz.U.z 2018 r. poz. 646 z późn. zm jednostki samorządu terytorialnego. Szczegółowym zadaniem KIS-ów może być podejmowanie działań nakierowanych na pomoc w znalezieniu pracy na czas określony, w pełnym lub niepełnym wymiarze czasu pracy u pracodawców, wykonywania usług na podstawie umów cywilnoprawnych oraz przygotowanie do podjęcia zatrudnienia lub podjęcia działalności $w$ formie spółdzielni socjalnej. Ponadto kluby prowadzić mogą prace społecznie użyteczne, roboty publiczne, poradnictwo prawne, działalność samopomocową w zakresie zatrudnienia, spraw mieszkaniowych i socjalnych oraz staże (art. 18 ust. 2 u.z.s.).

\subsection{Stowarzyszenia i fundacje}

Również w odniesieniu do stowarzyszeń i fundacji prowadzących działalność gospodarczą, jak i działalność pożytku publicznego (odpłatną i nieodpłatną), upatrywać można możliwych potencjalnych form wsparcia dla osób bezdomnych. Będzie to miało miejsce, jeśli taką możliwość przyjmie się $\mathrm{w}$ ramach tworzonego statutu, a następnie znajdzie to odzwierciedlenie w ramach faktycznej działalności konkretnego stowarzyszenia/fundacji.

W przypadku stowarzyszeń zwykłych, będących formą uproszczoną stowarzyszenia, prowadzenie przez nie działalności gospodarczej, (jak i odpłatnej działalności pożytku publicznego) jest z założenia wykluczone $^{20}$. Natomiast w pozostałych przypadkach stowarzyszeń, ustawodawca dopuścił możliwość prowadzenia przez nie działalności gospodarczej, przy jednoczesnym założeniu, iż dochód z niej służyć ma realizacji celów statutowych i nie może być przeznaczony do podziału między członków danego stowarzyszenia (art. 34 p.s.). Możliwość prowadzenia działalności gospodarczej nie wynika automatycznie z samej istoty stowarzyszenia, ale wymaga dodatkowego, szczegółowego wskazania w konkretnym statucie $\mathrm{w}$ odnie-

\footnotetext{
20 Art. 42 ust. 1 pkt. 3 i 4 ustawy z dnia 7 kwietnia 1989 r. Prawo o stowarzyszeniach, t.j. Dz.U. z 2017 r. poz. 210 z późn. zm., dalej: p.s.
} 
sieniu do konkretnego stowarzyszenia, które taką działalność zamierza podjąć. Jest to zatem pewna potencjalna możliwość/aktywność, którą stowarzyszenie może podejmować, ale wcale nie musi. Można wyrazić to i w ten sposób, iż prowadzenie działalności gospodarczej nie stanowi dla konstrukcji stowarzyszenia jego essentialia negotii. Jeśli jednak dane stowarzyszenie będzie aktywne w sferze gospodarczej, możemy wyróżnić dwie możliwe sytuacje. Po pierwsze, równolegle $\mathrm{z}$ rejestracją samego stowarzyszenia, jego założyciele od momentu jego powstania wprowadzają do statutu postanowienie o prowadzeniu działalności gospodarczej. Po drugie, następczo, dopiero w trakcie działalności danego stowarzyszenia może dojść do odpowiedniej zmiany statutu i podjęcia działalności gospodarczej. Dodatkowo, działalność gospodarcza stowarzyszenia przyjąć może postać niewyodrębnionej, ale również organizacyjnie wyodrębnionej. W tym pierwszym przypadku w obrocie występowało będzie po prostu samo stowarzyszenie, a użyty przez ustawodawcę zwrot, iż prowadzenie działalności gospodarczej odbywa się "według ogólnych zasad określonych w odrębnych przepisach" (art. 34 p.s.), oznaczał będzie odesłanie do stosownych w tym obszarze aktów prawnych (m.in. podatkowych, celnych czy też związanych z działalnością pożytku publicznego dla stowarzyszeń, które taki status uzyskają). Natomiast prowadzenie działalności gospodarczej $w$ formie wyodrębnionej oznaczało będzie sięgnięcie jeszcze i po te akty prawne, które regulują obraną przez stowarzyszenie formę. Przykładowo prowadzenie przez stowarzyszenie spółdzielni socjalnej, wiązało się będzie z koniecznością uwzględniania rozwiązań zawartych w u.s.s.

Natomiast stowarzyszenia, które będą prowadziły działalność odpłatną i nieodpłatną pożytku publicznego, opierać ją muszą na stosowych $\mathrm{w}$ tym zakresie przepisach u.d.p.p.w.
Konkretnych przykładów dostarcza chociażby działalność Stowarzyszenia "Otwarte Drzwi", którego celem jest m.in. przeciwdziałanie bezdomności i niesienie pomocy socjalnej, terapeutycznej, rehabilitacyjnej, materialnej osobom bezdomnym ${ }^{21}$. Również celem działań Towarzystwa Pomocy im. Św. Brata Alberta jest niesienie pomocy osobom bezdomnym poprzez m.in. zakładanie i prowadzenie schronisk, noclegowni, organizowanie pracy dla osób bezdomnych, jak i pomoc w reintegracji zawodowej i społecznej22.

Równolegle pośród fundacji prowadzących działalność gospodarczą oraz działalność pożytku publicznego szukać należy form wspierających osoby bezdomne. Będzie to miało miejsce $w$ przypadku odpowiedniego rozporządzenia masą majątkową przez fundatora, który postanowi przeznaczyćją na działania wspierające, inkluzyjne względem osób bezdomnych. Tak jest chociażby w przypadku Fundacji kapucyńskiej im. bł. Aniceta Koplińskiego ${ }^{23}$, jak i Domus et Labor. Fundacji Pomocy Bezrobotnym i Bezdomnym ${ }^{24}$.

\section{Podsumowanie}

Reasumując: każda $z$ form ekonomii społecznej, jako z założenia przeciwdziałających wykluczeniu społecznemu, może być uznana za przydatną w sensie pozytywnego, inkluzyjnego oddziaływania na sytuację osoby bezdomnej. Za szczególnie wartościowe i stwarzające znaczący potencjał $w$ analizowanym obszarze, postrzegam spółdzielnie socjalne [tak też: Medrzycki, 2016, s. 68-67], jak również CIS-y i KIS-y. Ponadto taką rolę mogą mieć stowarzyszenia, jeśli zakres działania konkretnego stowarzyszenia będzie obejmować działania na rzecz osób bezdom-

\footnotetext{
21 http://otwartedrzwi.pl/statut-2/.

22 http://www.bratalbert.org/files/brat_albert/pdf/Statut_2015.pdf.

${ }^{23}$ http://fundacja-kapucynska.org/wladze/statut/.

24 http://domusetlabor.manifo.com/statut-fundacji.
} 
nych. Natomiast w przypadku fundacji - statut może przewidywać, że osoby bezdomne mogą być podmiotami, na które nakierowane są działania fundacji, że cel fundacji obejmował będzie działania na rzecz ich aktywizacji i inkluzji.

W kontekście problematyki ekonomii społecznej warto również wyeksponować klauzule społeczne funkcjonujące $w$ ramach społecznie odpowiedzialnych zamówień publicznych [Piotrowska, 2017, s. 568-579], stosując je jako ważny element reintegracji osób bezdomnych, np. klauzula zatrudnieniowa pozwalająca wymagać, aby wykonawca do realizacji zamówienia publicznego zatrudnił osoby mające utrudniony dostęp do rynku pracy - osoby bezdomne [Mędrzycki, 2016, s. 67].

Ekonomia społeczna stwarza zatem potencjalne szanse, daje narzędzia, które

\section{Literatura}

Aleksander T. (2012). „Rekomendacja: wykluczenie społeczne a kształcenie dorosłych", w: Z. Szarota (red.), Oświata dorosłych wobec jednostek i grup defaworyzowanych. Ku społecznej jedności (s. 5-8). Kraków: Wydawnictwo Naukowe Uniwersytetu Pedagogicznego.

Blicharz J. (2017). „Ekonomia społeczna jako forma aktywności społecznej”, w: J. Blicharz, L. Zacharko (red.), Trzeci sektor i ekonomia społeczna. Uwarunkowania prawne. Kierunki działań (s. 219-226). Wrocław: Prawnicza i Ekonomiczna Biblioteka Cyfrowa. Wydział Prawa, Administracji i Ekonomii Uniwersytetu Wrocławskiego.

Gołębiowska K. (2015). Model spółdzielni socjalnej dla osób bezdomnych na przykładzie Spółdzielni Socjalnej Kwazar. Poznań: Stowarzyszenie Na Rzecz Spółdzielni Socjalnych.

Karta Praw Osób doświadczających bezdomności (bdw). https://www.rpo.gov.pl/sites/default/files/ Karta\%20Praw\%200s\%C3\%B3b\%20do\%C5\%9Bwiadczaj\%C4\%85cych\%20bezdomno\%C5\%9Bci.pdf.

Kostyło P. (2008). Wykluczanie jako problem filozofii edukacji. Komentarz do badań empirycznych. Kraków: Impuls.

Krajowy Program Przeciwdziałania Ubóstwu i Wykluczeniu Społecznemu 2020. Nowy wymiar aktywnej integracji (2014). Uchwała nr 165 Rady Ministrów z dnia 12 sierpnia 2014 r. przy przemyślanym wykorzystaniu mogą być przydatne do niwelowania zjawiska bezdomności. Stwarza możliwości aktywnej inkluzji, rozwijając swoje idee i zaangażowane społecznie założenia. Z całą pewnością jednak nie mogą być postrzegane jako antidotum władne rozwiązać wszelkie problemy, związane z tak skomplikowanym i wielowymiarowym zjawiskiem jak bezdomność. Każde jednakże działanie mogące realnie przeciwdziałać bezdomności uznać należy za wartościowe i pożądane do realnego urzeczywistniania. Ekonomia społeczna to innowacyjność, a tylko poprzez nowatorską próbę podejścia do problemu bezdomności można starać się zbliżyć do zmniejszenia skali problemów, jakie pociąga za sobą bezdomność.

Lipowicz I. (2013). „Bezdomni i wykluczeni też potrzebują opieki medycznej", w: I. Lipowicz (red.), O mądre i wrażliwe państwo (s. 130-133). Warszawa: Biuro Rzecznika Praw Obywatelskich.

Małecka-Łyszczek M. (2017a). "Zakres podmiotowy i klasyfikacja pojęcia "podmiot ekonomii społecznej»", w: J. Blicharz, L. Zacharko (red.), Trzeci sektor i ekonomia społeczna. Uwarunkowania prawne. Kierunki dziatań (s. 207-218). Wrocław: Prawnicza i Ekonomiczna Biblioteka Cyfrowa. Wydział Prawa, Administracji i Ekonomii Uniwersytetu Wrocławskiego.

Małecka-Łyszczek M. (2017b). Współpraca administracji publicznej z podmiotami ekonomii społecznej. Aspekty administracyjnoprawne. Warszawa: Wolters Kluwer.

Małecka-Łyszczek M. (2017c). „Inkluzja jako wartość w stanowieniu prawa administracyjnego na szczeblu centralnym", w: J. Zimmermann (red.), Aksjologia prawa administracyjnego, Tom I (s. 405-418). Warszawa: Wolters Kluwer.

Mędrzycki R. (2016). „Nowe formy działania administracji publicznej i partnerów społecznych w zakresie przeciwdziałania bezdomności", w: I. Lipowicz (red.), Bezdomność - problemy prawne, innowacyjne rozwiqzania (s. 62-74). Warszawa: Fundacja Didactics.

Mędrzycki R. (2017). Zadania administracji publicznej w zakresie przeciwdziałania bezdomności. Studium administracyjnoprawne. Warszawa: Wydawnictwo Uniwersytetu Kardynała Stefana Wyszyńskiego.

Moraczewska B. (2013). „Bezdomność. Definicja, problemy, rozwiązania obecne oraz historyczne 
odwołanie do ludzi luźnych", Studia Gdańskie. Wizje i Rzeczywistość, t. 10, s. 113-128.

MRPiPS (2017). Zmiany w spółdzielniach socjalnych pomoga bezdomnym, 9 marca, https://www.mpips. gov.pl/aktualnosci-wszystkie/pomoc-spoleczna/ art,8682,zmiany-w-spoldzielniach-socjalnychpomoga-bezdomnym.html.

MRPiPS (2018). Pokonać bezdomność. Program pomocy osobom bezdomnym. Warszawa: Ministerstwo Rodziny, Pracy i Polityki Społecznej.

\section{Akty prawne i orzecznictwo}

Rozporządzenie Ministra Rodziny, Pracy i Polityki Społecznej z dnia 14 lipca 2017 roku w sprawie przyznawania środków na podjęcie działalności na zasadach określonych dla spółdzielni socjalnych, Dz.U. z 2017 r. poz. 1379.

Ustawa z dnia 7 kwietnia 1989 r. Prawo o stowarzyszeniach, t.j. Dz.U. z 2017 r. poz. 210 z późn. zm.

Ustawa z dnia 27 sierpnia 1997 r. o rehabilitacji zawodowej i społecznej oraz zatrudnianiu osób niepełnosprawnych, Dz. U. z 1997 r. nr 123 poz. 776, z późn. zm. Ustawa z dnia 24 kwietnia 2003 r. o działalności pożytku publicznego i o wolontariacie, t.j.: Dz.U. z 2018 r. poz. 450, 650, 723 z późn. zm.
Piotrowska A. (2017). „Społeczne zamówienia publiczne jako sposób realizacji celów polityki społecznej", w: B. Dolnicki (red.), Sposoby realizacji zadań publicznych (s. 568-579). Warszawa: Wolters Kluwer.

Szarfenberg R., Żołędowski C., Theiss M. (red.). (2010). Polityka publiczna wobec ubóstwa i wykluczenia społecznego. Warszawa: Elipsa.

Sierpowska I. (2016). „Sytuacja prawna osoby bezdomnej - aktywne czy pasywne formy wsparcia?", w: I. Lipowicz (red.), Bezdomność - problemy prawne, innowacyjne rozwiązania (s. 29-51). Warszawa: Fundacja Didactics.
Ustawa z dnia 13 czerwca 2003 r. o zatrudnieniu socjalnym, Dz.U. z 2016 r. poz. 1828 z późn. zm.

Ustawa z dnia 12 marca 2004 r. o pomocy społecznej, t.j. Dz.U. z 2018 r. poz. 650, 700 z późn. zm.

Ustawa z dnia 20 kwietnia 2004 r. o promocji zatrudnienia i instytucjach rynku pracy, t.j. Dz.U. z 2017 r. poz. 1065 z późn. zm.

Ustawa z dnia 27 kwietnia 2006 r. o spółdzielniach socjalnych, Dz.U. z 2006 r. nr 94 poz. 651 z późn. zm.

Ustawa z dnia 9 czerwca 2011 r. o wspieraniu rodziny i systemie pieczy zastępczej, Dz.U. z 2011 nr 149 poz. 887 z późn. zm.

Wyrok z 13.06.1996 r. Sądu Apelacyjnego w Białymstoku I ACr 137/96, LEX nr 31797.

\section{The importance of social economy forms to counteract the phenomenon of homelessness}

Summary: The study analyzes selected forms of social economy through the prism of their "usefulness" in the inclusion of homeless people, in their empowerment. Therefore, it is about exposing what allows to overcome growing social exclusion, enabling a more complete participation of homeless people in social life, in communities forming within society.

Keywords: social economy, homelessness, inclusion, social exclusion.

\section{Prawa autorskie i licencja / Copyright and License}

